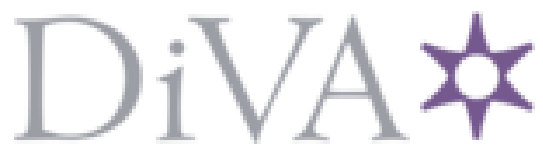

http://www.diva-portal.org

This is the published version of a paper published in Project Management Journal.

Citation for the original published paper (version of record):

Miterev, M., Engwall, M., Jerbrant, A. (2017)

Mechanisms of isomorphism in project-based organizations.

Project Management Journal, 48(5): 9-24

Access to the published version may require subscription.

N.B. When citing this work, cite the original published paper.

Permanent link to this version:

http://urn.kb.se/resolve?urn=urn:nbn:se:kth:diva-217388 


\section{Mechanisms of Isomorphism in Project-Based Organizations}

Maxim Miterev, Department of Industrial Economics and Management, KTH Royal Institute of Technology, Stockholm, Sweden

Mats Engwall, Department of Industrial Economics and Management, KTH Royal Institute of Technology, Stockholm, Sweden

Anna Jerbrant, Department of Industrial Economics and Management, KTH Royal Institute of Technology, Stockholm, Sweden

\section{ABSTRACT}

This article challenges the dominant assumption of goal rationality behind temporary organizations' design in project-based organizations (PBOs). While extant literature posits that organizations strive to select the most appropriate project arrangements to fit particular task requirements at hand, findings from an in-depth ethnography-inspired case study suggest that projects in PBOs tend to imitate each other's structures, strategies, and practices with little consideration of the potential performance effects. Building upon the new institutionalism, this article conceptualizes the PBO as an organizational field of temporary and permanent organizations embedded in wider organizational and institutional fields and explicates isomorphic processes among temporary organizations in PBOs.

KEYWORDS: project-based organization; temporary organization; organization design; institutional theory; isomorphic mechanisms

Project Management Journal, Vol. 48, No. 5, 9-24 (C) 2017 by the Project Management Institute

Published online at www.pmi.org/PMJ

\section{INTRODUCTION}

R ecent studies report that an increasing number of firms are using projects as the main organizing principle to achieve their strategic and operational objectives (Cattani, Ferriani, Frederiksen, \& Täube, 2011; Lundin et al., 2015; Whittington, Pettigrew, Peck, Fenton, \& Conyon, 1999). This trend is reflected in the growing scholarly interest in project-based forms of organizing within the strategic management and innovation literature (Blindenbach-Driessen \& Van den Ende, 2006; Brady \& Davies, 2004; Davies \& Brady, 2000, 2016; Gann \& Salter, 2000; Hobday, 2000; Keegan \& Turner, 2002; Loufrani-Fedida \& Saglietto, 2016; Nightingale, Baden-Fuller, \& Hopkins, 2011; Prencipe \& Tell, 2001; Söderlund, 2005, 2008; Whitley, 2006). While their effects on innovation and learning remain an intricate matter (Burgers, Van Den Bosch, \& Volberda, 2008; Keegan \& Turner, 2002; Sydow, Lindkvist, \& DeFillippi, 2004), project-based organizations are widely praised for their capacity to flexibly address changing customer demands, integrate diverse knowledge sets, bypass barriers to organizational change and innovation, and deliver complex non-routine tasks (Hobday, 2000; Nightingale et al., 2011; Sydow et al., 2004).

The literature on project-based organizations has been pervaded by the implicit assumption of goal rationality (Weber, 1978) throughout the past half century (c.f. Levitt, 2012; Middleton, 1967). For example, project-based firms adopt an array of learning mechanisms (Prencipe \& Tell, 2001), integrate project and business processes (Gann \& Salter, 2000), introduce new management practices (Bresnen, Goussevskaia, \& Swan, 2004), and manage intra-firm institutional contexts (Lindkvist, 2004; Morris \& Geraldi, 2011) in order to build up project capabilities and competences. Overall, current theory depicts this process as a deliberate action, carefully designed by top managers to improve performance. In the same vein, one of the major advantages of the projectbased organization is claimed to be that it creates idiosyncratic structures to fit specific project tasks (Bakker, 2010; Hobday, 2000). This perceived advantage is commensurate with the contingency perspective (Dvir, Lipovetsky, Shenhar, \& Tishler, 1998; Shenhar, 2001; Shenhar \& Dvir, 1996) and pinpoints performance pressure as the key determinant of project management structures and approaches. It also implies that structures and approaches are chosen by firms in a deliberate and rational way and that they exist in a rich variety in a PBO.

To date, however, several empirical studies have reported opposite evidence. For example, despite the fact that project-based organizations are theoretically well-suited to adapt structures and approaches when a new project starts from scratch, paradoxically, they rarely do so (Ekstedt, Lundin, \& Wirdenius, 1992). Moreover, even obvious improvements are often not 
introduced to ameliorate a challenging project situation (Brady \& Maylor, 2010). Furthermore, project-based management practices can be adopted by organizations even when they do not fit in well (Martinsuo, Hensman, Artto, Kujala, \& Jaafari, 2006). Thus, in order to explain such phenomena, the literature needs to build on a different set of theories.

New institutionalism in organization studies represents a promising candidate to provide an alternative explanation of project-based dynamics (Henisz, Levitt, \& Scott, 2012; Lampel, 2011; Manning, 2008; Sydow \& Staber, 2002; Windeler \& Sydow, 2001), because, as explained further, it successfully deals with similar issues within organization theory. With regard to the enactment of structures and approaches, projects as temporary organizations experience pressure from their institutional environment (Lundin \& Söderholm, 1995). Such pressure might result in a relatively low variation among temporary project organizations (Kadefors, 1995), since availability and familiarity heuristics affect their structures and routines (Eriksson \& Kadefors, 2017).

In order to explain what they called the "startling homogeneity" of organizations, DiMaggio and Powell (1983) built on the notion of organizational field, in other words, "those organizations that, in the aggregate, constitute a recognized area of institutional life: key suppliers, resource and product consumers, regulatory agencies, and other organizations that produce similar services or products" (ibid, p. 148), and specified isomorphic processes that lead to homogeneity among organizations as the organizational field evolves.

Building on the notion of a project as a temporary organization, this article posits that such isomorphism can be especially salient for intra-organizational projects. Indeed, organizational fields characterized by the high centralization of resource supply, uncertainty, and professionalization are particularly susceptible to institutional isomorphism (DiMaggio \& Powell, 1983). Accordingly, temporary organizations in projectbased organizations often compete for a limited centrally distributed pool of resources (Engwall \& Jerbrant, 2003), which enables coercive isomorphism. In addition, the 'one-off' character of projects and the impermanence of their organizational forms result in high uncertainty, which is positively associated with mimetic processes. Finally, the professionalization of project management (Hodgson, 2002) creates preconditions for normative isomorphic processes; thus, in the context of a project-based organization one would expect rather strong isomorphic processes in projects.

In order to investigate how such processes shape project management structures and approaches, this study employed an ethnography-inspired indepth case study approach. By conceptualizing the project-based organization as an organizational field of temporary and permanent organizations embedded in wider organizational and institutional fields, the study findings question the implicit rationality assumption dominant across the literature on PBOs. Specifically, by applying an institutional lens, the article explicates isomorphic processes (i.e., coercive, mimetic, and normative) in the context of projectbased organizations and shows how projects as temporary organizations 'imitate' each other, often with little or no focus on efficiency.

The article's contribution to the literature is threefold. First, building on the notion of a project as a temporary organization (Lundin \& Söderholm, 1995) it elaborates on the concept of project context within a $\mathrm{PBO}$, thus contributing to the contextual stream of literature on projects (Engwall, 2003; Grabher, 2004). While the extant literature focuses on organizational and wider institutional context (Bakker, 2010), this study shows how the portfolio of projects represents an important constituent of the internal PBO context (Bergman, Gunnarson, \& Räisänen, 2013). In other words, when scholars refer to projects as embedded in organizational context, they largely emphasize the linkages to the parent organization and its business processes (Gann \& Salter, 2000). However, projectto-project institutional mechanisms are generally overlooked. On the contrary, this study puts forth the lens on the project-based organization as an organizational field of temporary and permanent organizations. Second, the study challenges the goal rationality assumption behind temporary organization design and calls for a more nuanced understanding of institutional processes within the PBO. Finally, the article explicates the isomorphic processes at the level of temporary organizations in the particular context of project-based organizations.

The article is structured as follows. The second section discusses the theoretical background of the study; specifically, it starts by discussing the concept of temporary organization design by building on the notion of the project as a temporary organization and several models from the organization theory and design literature. Then, it critically evaluates the goal rationality assumption in the literature on project-based organizations and introduces the institutional perspective as the theoretical lens of the study. The section concludes by developing a novel conceptualization of the PBO that is used in the study. The third section describes in detail the research design and methodology; the fourth section presents the empirical findings; and, finally, the fifth section concludes the article with a discussion on the wider theoretical and managerial implications of the study.

\section{Theory}

\section{Temporary Organization Design in PBOs}

In general management studies, the organization design literature aims to understand the configurations, antecedents, and consequences of various interdependent management arrangements at the organizational level (Van de Ven, Ganco, \& Hinings, 2013). Building on this body of literature and on 
the notion of a project as a temporary organization (Lundin \& Söderholm, 1995), this study conceptualizes such arrangements at the levels of projects and programs as the temporary organization design (TOD). This subsection discusses various design dimensions at the temporary organization level.

The organization theory and design literature has proposed a number of organizational models encompassing different sets of design dimensions. Leavitt (1965) put forward four facets: task, technology, structure, and people. Alternatively, a popular 7S Model proposed structure, strategy, systems, style, skills, staff, and subordinate goals as key design dimensions (Pascale \& Athos, 1981; Peters \& Waterman, 1982). Along the same lines, Galbraith's Star Model ${ }^{\mathrm{TM}}$ (Galbraith, 1977, 2014) encompasses strategy, structure, processes, people, and rewards as the key organization design elements. The project management literature offers a similar set of design dimensions in the context of project-based organizations (Miterev, Mancini, \& Turner, 2017; Miterev, Turner, \& Mancini, 2017). For example, Hanisch and Wald (2011) used the dimensions of strategy and structure, project management and project organization, and culture and social processes. Bergman et al. (2013) derived four perspectives on organization from the literature-namely product, process, people, and structure-which they used to analyze both firm-based projects and their parent organization. Eriksson and Kadefors (2017), in their discussion on project organizational design, referred to organizational structures and routines for coordination. Building on these and similar sources, the temporary organization design is conceptualized as comprising four key dimensions that appear to be common in the models: structure, strategy, process, and people. In the remainder of the article, these four dimensions serve primarily as a framework to analyze the data and organize the arguments. Hence, the article does not claim that these four dimensions represent the ultimate TOD model.

The antecedents and consequences of various temporary organization design choices are still ambiguous despite their importance (Lechler \& Dvir, 2010). Within the context of the project-based organization we know even less about the dynamics of temporary organization design (Bergman et al., 2013), since much of the literature studies project arrangements separately from the organizational context (Engwall, 2003).

\section{The Assumption of Goal Rationality Behind TOD Choices in PBOs}

The dominant assumption behind the temporary organization design is that of the 'goal rationality' (Weber, 1978). In particular, the literature posits that project arrangements are selected rationally with the aim of increasing efficiency. As Hobday (2000) states: "PBOs organise their structures, strategies, and capabilities around the needs of projects ..." (p. 875). Similarly, Bergman et al. (2013) note that “... all aspects of a project need to be considered by the firm: a structure needs to be set up, the need for resources identified and made available, the relevant and viable processes and technologies identified for realizing the project outcome (the product)." (p. 112)

This assumption is commensurate with the contingency stream within the literature on projects, which posits that universally applicable management solutions hardly exist, in other words, 'onesize-does-not-fit-all' projects (Shenhar, 2001; Shenhar \& Dvir, 1996). The contingency perspective, which has gained considerable momentum in project management studies (Hanisch \& Wald, 2012; Miterev, Mancini, \& Turner, 2017), is traditionally linked to the rationalist stance. However, the claim of universally applicable goal rationality behind TOD remains a mere assumption rather than an empirical fact.

In organization theory, the contingency perspective has been found to be an important (but not exhaustive) theoretical pillar to explain observable organizational forms on its own (cf. Schoonhoven, 1981; Scott, 1995; Van de Ven et al., 2013). Empirical findings reported in the project management literature suggest that this view also seems to be valid for temporary organizations. Indeed, temporary organizations experience pressure from their institutional environment (Lundin \& Söderholm, 1995), which might lead to homogenization of project structures and approaches (Bergman et al., 2013; Kadefors, 1995). Moreover, learning among projects contribute to this process (Engwall, 2003; Prencipe \& Tell, 2001). Finally, observable patterns of actions do not necessitate the existence of prior calculated decisions (Lundin \& Söderholm, 1995). Specifically, various cognitive "rules of thumb," such as heuristics or biases, were found to influence temporary organization design (Eriksson \& Kadefors, 2017), indicating deviations from pure rational thinking. To conclude, these observations pose certain challenges to the assumptions and predictions of the contingency-based stream of the literature. Consequently, we call for a better understanding of institutional processes that shape temporary organization design in the context of the PBO.

\section{New Institutionalism and Isomorphic Processes}

The institutional stream of literature within organization theory has challenged the idea that the demands of technical activities necessarily determine the organization's design, for example, formal structure (Meyer \& Rowan, 1977). Instead of being primarily driven by the need for higher efficiency, organizations strive to achieve legitimacy in their organizational fields by incorporating institutional rules into their formal structures (ibid). In well-established organizational fields institutional pressure leads to a high homogeneity of organizational forms and approaches (DiMaggio \& Powell, 1983). The key 
process is denoted as isomorphism, in other words, "a constraining process that forces one unit in a population to resemble other units that face the same set of environmental conditions" (DiMaggio \& Powell, 1983, p. 149). Specifically, DiMaggio and Powell (1983) proposed an analytical typology of the isomorphic mechanisms-coercive, mimetic, and normative-leading to isomorphism among organizations.

Coercive mechanisms are related to external pressures exerted on organizations both by other organizations and wider society. These pressures can be both formal and informal requirements imposed on some organizations by organizations they depend on and can also reflect cultural expectations of appropriate actions in the immediate organizational environment and wider society.

Mimetic mechanisms are related to imitation among organizations, commonly triggered by environmental uncertainty. The imitation strategy under uncertainty allows organizations to find a seemingly workable solution at low cost (Cyert \& March, 1963). One of the factors that might contribute to isomorphism is the limited number of readily available models. In particular, organizations tend to imitate organizations from the same organizational field that they perceive to be successful or legitimate. Diffusion of the organizational models can occur via employee turnover, customer demands, and the activities of consulting firms or industrial associations.

Normative mechanisms are related to the effects of a shared cognitive base and emerge primarily from professionalization. Both through formal education and participation in professional associations, professional norms, organizational models, mind-sets, and problem-solving approaches become legitimized and diffused among professional managers. The human resource management (HRM) practices of selection, promotion, and training represent another important mechanism for spreading and/or strengthening normative isomorphism through limiting variation among managers.

\section{The PBO as an Organizational Field}

The study builds upon three key ideas from extant literature. First, it builds on the notion of the intra-organizational institutional field, which originates from the studies of multinational corporations (MNC) (Dörrenbächer \& Geppert, 2017; Ghoshal \& Bartlett, 1990; Kostova, Roth, \& Dacin, 2008). As Kostova et al. (2008) state: "all units in an MNC might be viewed as belonging to the same intra-organizational institutional field, which is contained within the boundaries of the firm" (p. 998). Such fields exert particularly strong influence over their members and are embedded in traditional external institutional fields (ibid).

Second, it follows the notion of a project as a temporary organization (Lundin \& Söderholm, 1995; Packendorff, 1995). While this view dominates the discourse on single project management, it does not receive equal attention within the literature on project-based organizations (Bergman et al., 2013). Within the PBO literature, projects are often seen as idiosyncratic business processes and their structures are not explicitly taken into account (Miterev, 2017). By contrast, in this study, temporary organizations are explicitly viewed as constituent elements of the intraorganizational institutional field.

Third, this study acknowledges the role of the project's organizational and institutional contexts (Engwall, 2003; Grabher, 2004). In particular, the study builds upon the clarification of the project context within a project-based organization (Bergman et al., 2013). Specifically, for a focal project within a project-based organization, all other projects carried out in the same parent organization comprise an important part of the project context. In addition, permanent organizational units, along with various governance institutions (Müller, 2009), constitute an integral part of the intra-organizational institutional setup of the PBO (Lindkvist,
2004). Finally, following the ideas that were developed in relation to project networks (Manning, 2008; Sydow \& Staber, 2002), the study views the PBO as embedded in wider organizational and institutional fields.

Building on these ideas, this study conceptualizes the project-based organization as an organizational field of temporary and permanent organizations embedded in wider organizational and institutional fields. Thus, the intra-organizational field of the PBO comprises the totality of temporary organizations, such as projects and programs as well as permanent organizational units (e.g., HR department), and various governance institutions. In such organizational fields, one can reasonably expect strong isomorphic pressure on temporary organizations. Indeed, temporary organizations in project-based organizations often compete for a limited centrally distributed pool of resources (Engwall \& Jerbrant, 2003), which enables coercive isomorphism. The 'one-off' character of projects and the impermanence of their organizational forms result in high uncertainty, which is positively associated with mimetic processes. Finally, a rather strong professionalization of project management (Hodgson, 2002) creates preconditions for normative isomorphic processes. In order to explicate the related processes, this study employs the classic analytical typology of isomorphic mechanisms, in other words, coercive, mimetic, and normative (DiMaggio \& Powell, 1983).

\section{Methodology \\ Research Design}

This article is based on an in-depth case study of project-based organizing in the operations division of a large pharmaceutical company. The study is inductive in nature, aiming to challenge and/or elaborate on existing theories of project-based organizing, rather than to test them (Eisenhardt, 1989). Thus, the resulting theoretical motivation presented in the Theory section is 
developed ex post, emerging from the concurrent data collection and analysis (Glaser \& Strauss, 1967; Suddaby, 2006). Inspired by the ethnographic approach (Fetterman, 2010), the study employs a range of data collection methods with a notable share of direct observations.

The case study research strategy provides several advantages to achieving the study purpose. First, the case study research strategy suits open-ended research inquiry into an interesting phenomenon in nascent streams of literature (Edmondson \& McManus, 2007). While the literature on project-based organizations has received scholarly attention (Cattani et al., 2011), few studies have paid close attention to the temporary organization design choices within the project-based organization despite their importance. Thus, the research strategy provided us with the necessary flexibility to discover rather serendipitous findings. Second, it enabled us to conduct the research simultaneously at two levels of analysis: the temporary organization level and the parent organization level. Whereas much of the extant literature on project-based organizations focuses on the level of the parent organization, the temporary organization level is often either overlooked or conceived based on disputable assumptions (Miterev, 2017). Finally, the research strategy is conducive to uncovering disconfirming evidence that questions assumptions behind existing theories.

For a single case study, the choice of the case company is crucial. The study followed a theoretical rather than probabilistic/random sampling. The projectbased organization encompassed a diverse set of temporary organizationsprojects and programs-with regard to their objectives, local versus international operations, organizational functions involved, management leadership styles, and so forth. In case temporary organization design dimensions could be linked to some of these contingency variables, this would provide an extension to existing theory. On the contrary, if the evidence suggested that such variation is low and/ or cannot be linked to the various contextual factors, then the implicit assumptions in the literature would be questioned. Data collection was arranged accordingly to cover several temporary organizations within the project-based organization, thus representing an embedded case study (Yin, 2009).

\section{Data Collection}

The study involved a wide range of data collection approaches and data sources commensurate with the case study strategy (Eisenhardt \& Graebner, 2007; Yin, 2009). Principal data collection methods included direct observations, semi-structured interviews, document analysis, and various research-related meetings with the company managers. The empirical data utilized in the study are summarized in Table 1.

A distinctive feature of this study is extensive use of direct observations in an everyday work environment (Fetterman, 2010). During the study one of the

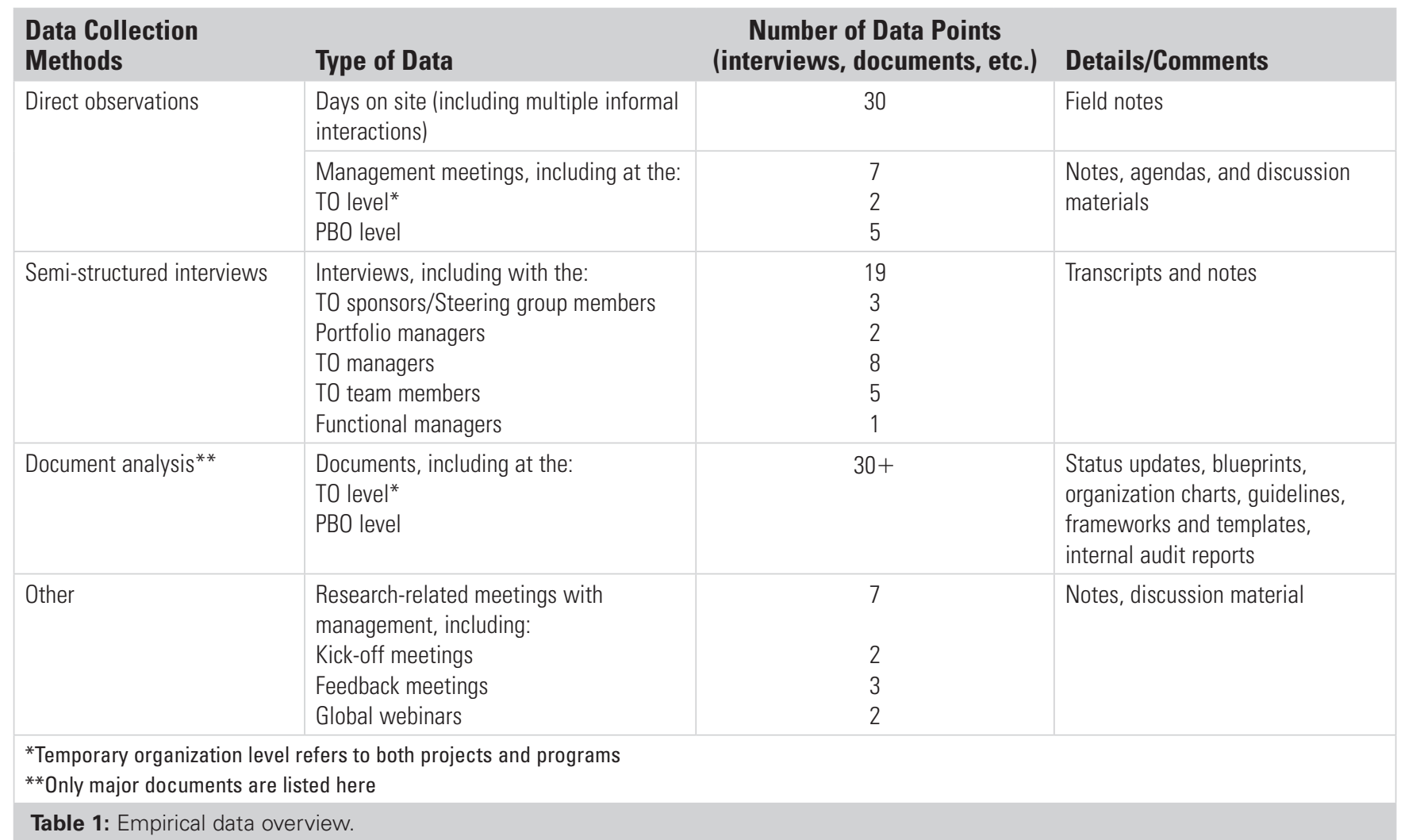


authors had his own work desk in the open-plan office space and unrestricted access to the company's facilities. This allowed the researcher to attend weekly planning meetings, to have multiple informal interactions with the staff during coffee breaks and lunches, to observe the visual communication graphs, and to closely follow everyday interactions among staff members. In total, the researcher spent between two and three days per week in the company office during ordinary office hours over three months, with a total of 30 full workdays spent on-site (approximately 240 hours of direct observations). Each day on-site resulted in a field note, either taken electronically or verbatim. The notes contained between one and four pages of bulleted points and sketches, which recorded key observations along with the immediate reflections and ideas to explore. Moreover, the researcher participated in seven formal meetings, including two regular progress meetings of two temporary organizations and five meetings of an organizational development group aiming to build up the project and program capability of the PBO. Most of the meetings lasted between one and four hours, with an average duration of around two hours. Overall, the ethnography-inspired observations allowed us to explore more covert aspects of the temporary organization design related to power structure and leadership styles, as well as to build trust in order to improve the effectiveness of the other data collection methods, such as interviews.

Semi-structured interviews represented another important source of data. In order to elicit the most valuable information from each respondent, several different interview protocols were prepared depending on the interviewee's position, expertise, and the estimated duration of the interview. The protocols covered two or three major themes involving open-ended questions about the ways in which the temporary organization is organized and the reasons for the design choices made.
With the original goal of understanding whether and how various factors influence temporary organization design, the interviewees were also asked about the differences between different temporary organizations in the organization that they were aware of. In total, 19 interviews were conducted, lasting on average slightly over one hour. The interviewees included managers of temporary organizations, steering group members, and other relevant actors, such as project portfolio managers or a head of a functional unit. The respondents were selected to represent different hierarchical levels, geographies, and organizational units to reduce biases and strengthen the credibility of the study (Eisenhardt \& Graebner, 2007). The interviews were recorded and later transcribed for subsequent data analysis. In addition, the researcher took notes during the interviews to allow for early engagement between data and theory (Glaser \& Strauss, 1967).

Direct observations and semistructured interviews were complemented with document analysis of two main types of documents. The first one included documents related to the organization and management of specific temporary organizations. Some examples included project and program blueprints, business cases, risk logs, progress reports, templates, and organizational charts. The second type represented the documents concerning the projectbased organization as a whole, which included numerous project, program, and portfolio management guidelines; frameworks and templates; goal-setting documents, such as the project and program capability development roadmap; and the internal audit reports. The internal audit reports were found to be a particularly valuable source of data. First, they were conducted by employees not involved in the everyday work of the project-based organization and, as such, represented an external point of view allowing for triangulation of the data and a reduction of self-report bias. Second, they typically covered a wide range of issues, and provided a comparison across various temporary organizations. The documents provided yet another point of triangulation in addition to the interviews and observations. Any discrepancies between them were investigated further.

The final source of data represented notes from several meetings of the research team with company management. These included two initial meetings discussing the scope of the research project; three meetings (two interim and one final) devoted to the discussion of research findings with company management; and two global webinars for the wider members of the competence network on project, program, and portfolio management, both including Q\&A sessions. These meetings allowed for the collection of additional data and feedback on preliminary conclusions.

The process of data collection was completed when a theoretical saturation was reached (Bryman \& Bell, 2007; Eisenhardt, 1989; Glaser \& Strauss, 1967).

\section{Data Analysis}

The data analysis was conducted in parallel to the data collection process, in agreement with the inductive research design. It was the data, rather than any extant theory, that guided the data analysis (Glaser \& Strauss, 1967). The approach allowed us to maintain flexibility and provided opportunities to discover serendipitous findings. This subsection presents the data analysis chronologically.

Approximately one month from the beginning of data collection, we reviewed the extant literature looking for discrepancies between the extant theory and emerging data. One such discrepancy emerged as a rather unexpected finding. Namely, we discovered that projects in the PBO were not that different from each other compared with what the literature on project-based management rooted in contingency theory would predict (see Dvir et al., 1998; Hobday, 2000; Shenhar, 2001; Shenhar \& Dvir, 1996). Indeed, given the broad 
variations of preconditions and objectives of various temporary organizations within the PBO, we expected to discover a considerable variation of their organization designs. However, what emerged was that the temporary organization designs resembled each other to a notable extent; in addition, we also came across examples of temporary organizations imitating each other and decided to explore this issue further.

The data analysis involved multiple iterations back and forth between the data collection and theory development. Two broad stages can be distinguished in this process. During the first stage, the analysis was mainly conducted "bottom-up." Because we were not able to make sense of the observed phenomenon based on the extant PBO literature, we looked through the data for potential explanations. Three major themes started to emerge, which seemed to be linked to the low variability among temporary organizations: 'top-down prescription,' 'imitation,' and 'common background of managers.' As these themes resembled explanations of reasons for isomorphism within the new institutionalism in organization studies, it was considered a promising line of inquiry. Thus, in the second stage, we decided to draw upon the seminal work of DiMaggio and Powell (1983) in order to explicate the related processes within the PBO. A two-level coding system was used. The first level represented the three isomorphic mechanisms: coercive, mimetic, and normative (DiMaggio \& Powell, 1983). The second level included more detailed specific mechanisms falling under the first-level categories. In order to avoid forcing the theory on the evidence, the data were additionally reviewed with the aim of finding alternative or additional explanations of the phenomenon.

During the data analysis the evidence was grouped both by the temporary organization design dimensions and by the high-level isomorphic mechanisms. What emerged, however, was that most often the same mechanisms affected several of the design dimensions, so in the final representation of the findings in the Results section the evidence was structured based on the isomorphic mechanisms, whereas the TOD dimensions were indicated in italics.

We followed some of the recommendations of Eisenhardt and Graebner (2007) in presenting the empirical data, by adapting them to the single case study research. In particular, the Results section is structured according to the emerging theoretical constructs along with their empirical evidence. In addition, we used a tabular representation of the data along with selective story descriptions to summarize the evidence and illustrate the emerging causal links.

The rigor of a case study research can be assessed through four criteria: internal validity, construct validity, external validity, and reliability (Eisenhardt, 1989; Gibbert, Ruigrok, \& Wicki, 2008; Yin, 2009). While management scholars tend to emphasize the external validity, that should not be done at the expense of more fundamental assessment criteria, such as internal and construct validity (Gibbert et al., 2008). Table 2 presents a set of measures taken to corroborate the rigor of the study; for example, the bottom-up data analysis process ensured a tight link between constructs and data and thus strengthens the internal validity (Eisenhardt \& Graebner, 2007; Suddaby, 2006). Furthermore, the documentation of empirical evidence and the use of methodological triangulation strengthened reliability (Yin, 2009). During the study we also strived to pay attention to alternative theoretical explanations, in particular, the contingency theory (Gibbert et al., 2008).

\section{Results}

\section{Variability of Temporary Organization Design}

There was relatively low variability of temporary organization design across various organizational initiatives in the project-based organization in terms of their structures and approaches. This finding is supported by several internal documents, including internal audit reports comparing organizational programs across various functions. Namely, the reports observed high compliance to the frameworks and standards and treated deviations as problematic and unacceptable. After consulting with the quoted guidelines and frameworks, we found that they covered a number of issues related to all four aspects of the organization design identified in the Theory section. This was further confirmed with the interviewees, who were asked whether and why different

\begin{tabular}{|l|l|l|}
\begin{tabular}{|l|l|} 
Research Credibility \\
Criteria
\end{tabular} & $\begin{array}{l}\text { Measures Taken to } \\
\text { Strengthen the Rigor }\end{array}$ & $\begin{array}{l}\text { Sources of } \\
\text { Recommendation }\end{array}$ \\
\hline Internal validity & $\begin{array}{l}\text { Deriving an explicit research } \\
\text { framework from extant literature } \\
\text { Pattern matching } \\
\text { Theory triangulation }\end{array}$ & $\begin{array}{l}\text { (Gibbert et al., 2008), } \\
\text { (Yin, 2009), } \\
\text { (Eisenhardt \& Graebner, 2007) }\end{array}$ \\
\hline Construct validity & $\begin{array}{l}\text { Data triangulation } \\
\text { Clear chain of evidence } \\
\text { Explanation of data analysis }\end{array}$ & $\begin{array}{l}\text { (Gibbert et al., 2008), } \\
\text { (Yin, 2009) }\end{array}$ \\
\hline External validity & $\begin{array}{l}\text { Nested approach to case study } \\
\text { (different case studies within one } \\
\text { organization) } \\
\text { Rationale for the case study } \\
\text { selection }\end{array}$ & $\begin{array}{l}\text { (Gibbert et al., 2008), } \\
\text { (Yin, 2009) }\end{array}$ \\
\hline Case study database & (Gibbert et al., 2008), \\
\hline (Yin, 2009)
\end{tabular}

Table 2: Measures taken to strengthen reliability and validity. 
organizational endeavors are organized differently. Using this observation as a starting point, we inquired into the possible reasons and discovered several mechanisms, which were conducive to isomorphism.

\section{Coercive Mechanisms}

Coercive mechanisms appeared in various forms in the project-based organization. A number of internal organizational guidelines and frameworks mandated specific structures and practices for nearly all aspects of project and program management. Compliance to the guidelines was ensured through a three-level assurance framework, comprising embedded policies at the team level, the independent functional level, and the organization-wide internal audit level. Finally, different key projects and programs reported to the same board members and appeared to follow their demands and expectations. Together, these mechanisms appeared to be important determinants of all aspects of the design of various temporary organizations, thus contributing to low structural variability. The empirical evidence on the coercive isomorphic pressure is structured according to specific mechanisms and is discussed in relation to the four organization design dimensions identified in the Theory section: structure, strategy, process, and people.

\section{Prescriptive Guidelines and Frameworks}

A multitude of formal frameworks and guidelines comprised the cornerstone of the coercive mechanisms and covered all aspects of the temporary organization design.

For example, the PBO's guide to program management and the project management framework prescribed in great detail the processes of the temporary organizations and their management structures; moreover, two specific templates provided the list of documents and structures that should be created during all project and program phases, thus defining a large part of management processes.

Similarly, the company's Prioritization Framework detailed how project and program strategy should be aligned to the corporate strategy captured in a set of strategic priorities. This linkage was further reinforced through a specified management process ensuring the strategic alignment. The requirements to program blueprints elaborated on in the guidelines provided another restriction on strategy; in addition, the benefits management section within the guide to program management discussed structures and processes, which need to be set up to implement the strategy.

Various guidelines that addressed capability building, in turn, affected the people dimension. These documents prescribed procedures and criteria for employee selection and promotion. Specifically, they detailed three clusters of competences related to leadership, core professional, and technical aspects. In order to be a part of a project team, an employee was assessed against the detailed description of each competence area in order to qualify; thus, the HR procedures were uniformly applied across various projects and programs in an organization-wide manner.

These examples provide an idea of the comprehensiveness of formal prescriptions embodied in extensive manuals and guidelines in the company. These guidelines were made mandatory and created pressure for the homogenization of various aspects of temporary organization design.

\section{Project Management Assurance System and Internal Audits}

Compliance with the various guidelines and frameworks was enforced via a comprehensive global standard on project and program management assurance. One of the most salient assurance measures was the system of internal audit. Occasionally, upper management commissioned organizationwide audits that randomly selected a sample of temporary organizations in various functions and provided global internal audit reports on all aspects of management.

Internal audits predominantly focused on the degree to which the processes were followed and the existence of certain documents, rather than on the performance or idiosyncrasies of the structure used to fulfill a projectspecific task. Even more importantly, many of the requirements were applied across a wide range of projects, including projects and programs within operations, research and development (R\&D), human resources (HR), and information systems (Internal Audit Report). As one program manager put it:

"I think that's where these audit reports fail-in seeing things holistically. What they actually look at is: "Do you have these, and these, and these, and these things?" (Program Manager)

Indeed, getting the 'green' status from an audit group was considered very important by the managers of temporary organizations and influenced their behavior.

The internal audits had important implications for the homogenization of temporary organization design on two levels. First, project and program managers had to fix the identified shortcomings, for example, by creating missing documents or formally assigning certain roles to team members. Second, the reports occasionally recommended top managers to revise existing frameworks or add new ones. Overall, the audit reports contributed to standardization of processes and structures.

\section{Expectations of Steering Group Members}

In addition to the formal prescriptive documents, there was also an informal component to the coercive isomorphic pressure. In particular, there was a large overlap of the steering group members across various programs and projects, with few top executives overseeing several key initiatives. The fact that different projects and programs 
reported to the same executives had an effect on many aspects of temporary organization design.

For example, strategy of temporary organizations was affected because of the alignment to the personal preferences of the sponsor and, more generally, the steering group members. Those preferences could be based on internal organizational politics and purely subjective preferences. The steering group members made important decisions with regard to continuation or termination of the initiative ('go-no go') and decided what resources should be assigned to the projects. Senior manager perceptions of the temporary organization managers' competency and effectiveness could also have important implications for their careers. All in all, many managers tried to align the temporary organization strategy to the expectations and preferences of a few steering group members, thus contributing to isomorphism.

The expectations also affected processes in terms of which aspects received more attention at regular stage-gate reviews. Executives had their preferred ways of reporting progress and expected various projects to adhere to these ways. As one of the executives put it:

\footnotetext{
"[When you as a project manager report to the board] you need an agenda, and a standard agenda really." (Member of a steering group)
}

Overall, this informal influence provided a subtler mechanism for shaping temporary organization design; this subtlety, however, does not mean that the effects were small. Rather, they tended to affect areas more difficult to regulate with formal prescriptions, such as strategic decisions.

In conclusion: All aspects of temporary organization design, including strategy, structures, processes, and people were affected by coercive isomorphic pressure. Specific complementary mechanisms identified in the study include the prescriptive guidelines and frameworks, project management assurance system and internal audits, as well as expectations of steering group members.

\section{Mimetic Mechanisms}

There was also a great deal of imitation among temporary organizations, which also contributed to the homogeneity. A crucial precondition for such imitation was that some temporary organizations and/or their managers were perceived as more successful and credible than others. This internal social structure did not appear to be a result of an impartial reflection of the competency, as some managers took active actions to promote and institutionalize their approaches. For instance, the 'best practice' reports often lacked analysis of the mistakes made and concentrated more on the success factors.

\section{Post-Closure and Lessons Learned Reports}

Upon completion of the project or program, managers were required to run a lessons learned session and fill out a closure report. Some managers went beyond this and wrote reports on their programs and/or the specific approaches used, which were later disseminated as best practice reports both to colleagues (other managers) and top executives. Such best practice reports were occasionally co-authored with top managers of the organization, which added extra importance and credibility to such internal publications. The reports contributed to structural rigidity because they encouraged the use of 'proven' approaches rather than experimentation with new ones; therefore, the available options to use as role models were essentially limited to a few 'star' projects and programs.

Two TOD dimensions, which seemed to be most affected by this mechanism were structure and processes. Among one of the many similar examples, one of the major change initiatives resulted in the report, "[The Company] Operations Program Office: An Introduction to a Successful Approach to Drive Efficiencies in Large Cross-Functional Organizations."
This report provided recommendations on the organizational structure of a program office, its communication flow patterns with other parts of organization, the process followed, and critical success factors. In addition, the Program Office Handbook included a comprehensive toolkit of guidelines, templates, and some details on the process followed.

\section{Sharing Approaches Within Formal Communities of Practice}

Much communication occurred through designated channels such as formal communities of practice-one of them was the Project, Program, and Portfolio Competence Network. The intranet forum of the network functioned as an active communication platform where managers exchanged tools and templates and answered questions. Occasionally, the network organized worldwide webinars on specific topics. The activities were supported with an internal online corporate academy offering a range of courses and training on various aspects of project, program, and portfolio management. Finally, a formal mentorship/coaching program within the network was in the process of introduction at the time of the study. The program was expected to contribute to the homogeneity by reinforcing the social structure among the managers of temporary organizations, with 'star' managers as role models and all others on the periphery. Together, a range of communication channels contributed to quicker dissemination of management approaches and particularly affected the processes dimension.

\section{Informal Networking Within Unofficial Groups/Coalitions of Managers}

A pivotal role for mimetic processes was played by unofficial coalitions of managers, which were often based on common vested interests, friendship, spatial proximity/colocation, and shared experiences. Some characteristics of the communication in coalitions included even higher within-group agreement, high level of trust, and informal one-to-one 
communication (e.g., face-to-face communication or email).

Some exchange of methods and tools happened this way, primarily affecting the processes (through the exchange of tools and templates) and, to some extent, structure (through discussion of appropriate organizational structures). The only difference with communities of practice was the speed of dissemination. While in the case of a best practice report or a communities of practice forum discussion, it could take some time before the tool was delivered and explained to a manager in need; in the case of the informal networking within a coalition, a telephone call would suffice. This mechanism also heavily influenced temporary design dimensions less affected by coercive mechanisms, such as strategy and people. The influence on the temporary organization's strategy included exchanging opinions about various stakeholders and having discussions on who should be in the steering group for a particular project or program. The people dimension was primarily affected by soliciting advice on who could be a good addition to the team based on the assessment of the credibility and competence of the potential candidate by other members of the coalition.

In conclusion: All aspects of temporary organization design, including strategy, structures, processes, and people were affected by mimetic isomorphic pressure. Specific complementary mechanisms identified in the study include the post-closure and lessons learned reports, sharing approaches within formal communities of practice, as well as informal networking within unofficial groups and/or coalitions of managers.

\section{Normative Mechanisms}

The third type of isomorphic mechanisms-normative mechanisms-was related to a similarity of cognitive bases and mental models of the temporary organization managers. Most of the managers were not members of any project management professional associations; however, when the managers were tasked with a development or an update to the company's guidelines and frameworks, they consulted with external sources and borrowed models and ideas such as those from Project Management Institute (PMI), International Project Management Association (IPMA), and best-selling publications on the topic of project management.

The similarity in the normative base of the managers was primarily maintained by several institutional mechanisms on multiple levels, including the societal level, industry level, and company level. The toolkit that managers used to conduct the analysis and come up with certain decisions was significantly informed by popular management models. Wider social norms and priorities also played important roles, for example, by convincing managers to consider the environmental impact of their decisions. At the industry level, the heavily regulated environment of the pharmaceutical industry was reflected in a high tolerance of the managers for structures and reports, which provided an additional common denominator to their approaches. In addition, the managers were a homogeneous group in terms of educational and professional backgrounds, gender, and psychological characteristics, all of which could have affected the similarity of their cognitive base.

\section{The Influence of Professional Associations}

Although none of the interviewed managers of temporary organizations was a member of any professional associations related to project, program, and portfolio management, their influence was noticeable. Various internal documents incorporated and referred to frameworks, definitions, and models from a few project management bodies of knowledge, including the International Project Management Association (IPMA) and its branches, such as the United Kingdom's Association of Project Management
(APM); Project Management Institute (PMI); as well as other organizations, including the United Kingdom's Office of Government Commerce (OGC). When some managers were tasked with developing certain internal guidelines or frameworks, they seemed to look for readily available outside solutions; because these models are relatively easy to find online, they ended up in the companies' frameworks and guidelines. All in all, since these models are relatively few and generally promote onesize-fits-all reasoning, the influence of project management associations has contributed to the normative isomorphic pressure.

\section{The Influence of Popular Management Models and Wider Societal Norms}

Some popular management models were widely used across temporary organizations, contributing to the similarity in management process-two notable examples include Ishikawa diagrams and various Lean tools, such as A3 problem solving. Many of the managers were familiar with the tools, which were also incorporated into various documents without additional explanations, indicating that they were part of the shared cognitive base within the company. Overall, some general management models represented easily accessible, comprehensible, and legitimate tools for the managers. There was no concerted effort to diffuse these models; they just appeared to be at least superficially known by many of the managers.

Consulting companies represented another driving force behind the dissemination of prescriptive models. In one case, several management consulting firms presented their proposals on how to organize a large project. Even though the company eventually chose to run the project on its own, it was exposed to the preliminary solutions during the pre-tender phase, which might have influenced their thinking. In another case, a whole IT-related project was accomplished in close collaboration with a top management consulting firm. 
Wider social norms appeared to influence the choices of managers; for example, the issues of sustainability in operations and outcomes were widely presented in nearly all company documents, both at the PBO level and the project and program levels.

\section{The Influence of Industry-Specific Norms}

Industry-related norms contributed to the similarity in cognitive base, because all interviewed managers of the temporary organizations possessed considerable experience in the pharmaceutical industry (at least five years). For example, the pharmaceutical industry is characterized by a highly regulated environment; many aspects of $R \& D$, operations, and marketing are subject to external regulations, including the process of drug approval, Good Manufacturing Practices (GMP), legislation related to tracing origins of ingredients, and advertising restrictions. Over their careers in the industry, managers are becoming accustomed to following external regulations; thus, heavy documentation and prescriptions are viewed as the norm. As one of the interviewees stated:

"We have GMP here ... and you have to keep a record of everything and that also influences other things, like our health policy, our environmental policy; we kind of think that way so we generate structures for things not regulated by law, you know, so we're kind of putting too much structure on things that are not related to the core business." (Program Manager)

\section{Similarity of Managers (Due to HRM Practices)}

Managers of temporary organizations represented a strikingly homogeneous group of people. The managers were almost exclusively engineers by educational background; in terms of professional background-all had been working in the pharmaceutical industry for a long period of time, primarily in two areas (chemical engineering and construction) and one function (operations), however, the project management background was not a prerequisite. Finally, all of the interviewed temporary organization managers were middle-aged men and shared some psychological characteristics; for example, during a leadership session run by an external organization, it was revealed that all but one of them were extroverts based on a personality test.

This similarity could be at least partially attributed to the HRM practices in the organization. The HRM guidelines had detailed descriptions of various competence areas relevant to the role.
The selection requirements, combined with the relatively homogeneous staff to choose from, resulted in a quite homogeneous group of temporary organization managers. For example, while there was no formal requirement that project managers had to be chemical engineers from the operations division, this turned out to be the case. A possible explanation of this fact can be related to HR traditions or path dependency rather than the formal requirements.

In conclusion: All aspects of temporary organization design, including strategy, structures, processes, and people were affected by normative isomorphic pressure. Specific complementary mechanisms identified in the study include the influence of professional associations, influence of popular management models and wider societal norms, influence of industry-specific norms, as well as similarity of managers (due to HRM practices). Thus, the mechanisms that led to the homogeneity of project management structures and approaches are summarized in Table 3.

\section{Discussion and Conclusion}

The purpose of the study was to explore how temporary organization design dimensions are shaped in the projectbased organization. In order to achieve

\begin{tabular}{|c|c|c|c|c|c|}
\hline \multirow{2}{*}{$\begin{array}{l}\text { Isomorphic } \\
\text { Mechanisms }\end{array}$} & \multirow[b]{2}{*}{ Specific Mechanisms } & \multicolumn{4}{|c|}{$\begin{array}{l}\text { Affected Temporary Organization Design } \\
\text { (TOD) Dimensions }\end{array}$} \\
\hline & & Structure & Strategy & Process & People \\
\hline \multirow[t]{3}{*}{ Coercive } & Prescriptive guidelines and frameworks & + & + & + & + \\
\hline & Project management assurance system and internal audits & + & & + & \\
\hline & Expectations of steering group members & + & + & + & \\
\hline \multirow[t]{3}{*}{ Mimetic } & Post-closure and lessons learned reports & + & & + & \\
\hline & Sharing of approaches within formal communities of practice & & & + & \\
\hline & Informal networking within unofficial groups/coalitions of managers & + & + & + & + \\
\hline \multirow[t]{4}{*}{ Normative } & Influence of professional associations & + & & + & \\
\hline & Influence of popular management models and wider societal norms & & & + & \\
\hline & Influence of industry-specific norms & & + & + & \\
\hline & Similarity of the managers (due to HRM practices) & & & & + \\
\hline
\end{tabular}


this purpose, the study employed an indepth embedded case study strategy with a significant ethnographic component. A rather unexpected finding of a limited structural variability of various temporary organizations prompted further exploration of the phenomenon. Building on the new institutionalism in organizational analysis, the study explicated ten mechanisms that push temporary organizations toward homogeneity in the PBO context and related various mechanisms to the specific TOD dimensions.

This article offers three interrelated contributions to the theory. First, the article questions the goal rationality assumption of the project-based organization literature. Second, it puts forth a novel conceptualization of the projectbased organization as an organizational field of temporary and permanent organizations embedded in wider organizational and institutional fields. Finally, building on this conceptualization, it applies the new institutionalism perspective to an intra-organizational problem and explicates the isomorphic processes in the context of projectbased organizations.

Assuming these findings are generally valid, they have several implications for the research on project-based organizations. First, the results provide insights for the discourse on the tensions between standardization and customization of project practices. In prior literature, the standardization pressure was linked to the parent organization's intent to control temporary organizations by top-down means (Bergman et al., 2013), in other words, coercive mechanisms. Current study complements this view by showing how other mechanisms, for example, imitation and similarity of cognitive base, might reinforce the coercive measures and contribute to the homogeneity of temporary organizations.

Second, the study illustrates the untapped power of the institutional perspective in relation to intraorganizational phenomena in the project-based setting. There is a need for a more nuanced understanding of institutional dynamics around temporary organizations (Engwall, 2003; Lampel, 2011; Lundin \& Söderholm, 1995). One of the promising research directions is to build upon institutional entrepreneurship literature (Battilana, Leca, \& Boxenbaum, 2009) to explore the intraorganizational institutional dynamics of PBOs. Namely, there is a need to understand how certain temporary organization managers enact and institutionalize their practices, safeguard their positions as opinion leaders, and the consequences of their actions. One of the promising lines of inquiry is to build on the different types of legitimacy-pragmatic, moral, and cognitive (Suchman, 1995) - in order to explain why some temporary organizations or their managers serve as role models for others.

Third, the findings inform the debate on alternative explanations on temporary organization dynamics in the project-based context, in other words, contingency and institutional perspectives. While the contingency perspective has proved to be useful in analyzing phenomena at different levels within PBOs (Kock, Heising, \& Gemünden, 2016; Miterev, Engwall, \& Jerbrant, 2016; Pemsel, Müller, \& Söderlund, 2016; Teller, Kock, \& Gemünden, 2014), the institutional perspective offers an important complementary explanation. Specifically, the study provides disconfirming evidence against the dominant assumption of goal rationality and shows how internal efficiency might not represent the principal driver behind a temporary organization design.

One characteristic of the study is that it was conducted in the highly regulated context of the pharmaceutical industry. While it is possible that in other contexts the strength of the isomorphic effects might vary, there are reasons to believe that isomorphism is generally a strong phenomenon across many PBO contexts. These reasons include the dependence of intra-organizational projects on a single source of financing (the parent organization), the inherent uncertainty of temporary operations, and the strong professionalization of project management. As an example, the need to create 'skunk works projects' to deal with particularly complex or exploratory tasks (Miller, 1995; Rich \& Janos, 1994) might be explained by their ability to escape the isomorphic pressure of the PBO by avoiding 'red-tape' activities that hinder focusing on the technical content (Engwall \& Westling, 2004). Moreover, recent behavioral studies have associated imitation strategy with levels of stress, distractions, and time pressure (Buckert, Oechssler, \& Schwieren, 2017). Therefore, since such preconditions are quite typical for multi-project environments (Zika-Viktorsson, Sundström, \& Engwall, 2006), one would expect imitation to be a common heuristic among project actors. Nevertheless, it is an important future line of inquiry to investigate the interrelation of alternative explanations (contingency and institutionalism) in various $\mathrm{PBO}$ contexts.

Fourth, the reasons described above also point toward the potential boundaries of isomorphism pressures. For example, inter-organizational projects might experience weaker isomorphism processes than their intra-organizational counterparts. Future research should identify how two (or more) compliances to different institutional environments in two (or more) different parent organizations collide and then reconcile.

Fifth, the results of this study call for a distinction between the concepts of imitation and learning. While the latter has a positive connotation and implies beneficial outcomes of the process (e.g., in terms of improved performance), the former can potentially result in lower performance. In addition, imitation can happen as a result of subconscious actions, whereas learning appears to imply a directed effort. Based on these distinctions, the findings of this study point toward a potential alternative explanation of why interproject learning (e.g., Prencipe \& Tell, 2001) and renewal/improvement (Brady \& Maylor, 2010; Ekstedt et al., 1992) 
can be challenging. In particular, the identified array of isomorphic mechanisms, including mimetic ones, can create institutional pressure leading to rejection of potentially beneficial new practices, thus impeding learning in the project-based organization.

A sixth research implication is methodological and relates to the need to conduct multi-level research within project-based organizations. While much of the extant research only addresses the PBO level, it is important to study the level of temporary organizations as well. This is because a neglect of temporary organization dynamics can result in inappropriate organization-wide arrangements (Engwall \& Westling, 2004). If we take the project as a temporary organization perspective seriously, we should borrow theories from the organization theory and design and apply them to temporary organizations within the PBO too.

\section{Acknowledgments}

This paper is produced as part of the EMJD Programme European Doctorate in Industrial Management (EDIM) funded by the European Commission, Erasmus Mundus Action 1.

We are grateful to Hans Georg Gemünden, Joana Geraldi, Miia Martinsuo, Lauri Vuorinen, Fredrik Tell, Graham Winch, Anette Hallin and Christian Berggren for a number of valuable comments on previous drafts of the manuscript. We would also like to thank the anonymous reviewers of the EURAM Conference 2017 and the Project Management Journal ${ }^{\circledR}$, for their constructive and helpful suggestions.

\section{References}

Bakker, R. M. (2010). Taking stock of temporary organizational forms: A systematic review and research agenda. International Journal of Management Reviews, 12(4), 466-486. doi.org/10.1111/ j.1468-2370.2010.00281.x

Battilana, J., Leca, B., \& Boxenbaum, E. (2009). How actors change institutions: Towards a theory of institutional entrepreneurship. The Academy of
Management Annals, 3(1), 65-107. doi.org/10.1080/19416520903053598

Bergman, I., Gunnarson, S., \& Räisänen, C. (2013). Decoupling and standardization in the projectification of a company. International Journal of Managing Projects in Business, 6(1), 106-128. doi.org/10.1108/ 17538371311291053

Blindenbach-Driessen, F., \& Van den Ende, J. (2006). Innovation in projectbased firms: The context dependency of success factors. Research Policy, 35(4), 545-561. doi.org/10.1016/

j.respol.2006.02.005

Brady, T., \& Davies, A. (2004). Building project capabilities: From exploratory to exploitative learning. Organization Studies, 25(9), 1601-1621. doi.org/10.1177/0170840604048002

Brady, T., \& Maylor, H. (2010).

The improvement paradox in project contexts: A clue to the way forward? International Journal of Project Management, 28(8), 787-795. doi.org/10.1016/j.ijproman.2010.08.001

Bresnen, M., Goussevskaia, A., \& Swan, J. (2004). Embedding new management knowledge in project-based organizations. Organization Studies, 25(9), 1535-1555. doi.org/10

$.1177 / 0170840604047999$

Bryman, A., \& Bell, E. (2007). Business research methods: Social research (2nd ed.). New York, NY: Oxford University Press.

Buckert, M., Oechssler, J., \& Schwieren, C. (2017). Imitation under stress. Journal of Economic Behavior \& Organization, 139(December), 252-266. doi. org/10.1016/j.jebo.2017.04.014

Burgers, J. H., Van Den Bosch, F. A. J., \& Volberda, H. W. (2008). Why new business development projects fail: Coping with the differences of technological versus market knowledge. Long Range Planning, 41(1), 55-73. doi.org/10.1016/j.lrp.2007.10.003

Cattani, G., Ferriani, S., Frederiksen, L., \& Täube, F. (2011). Project-based organizing and strategic management: A long-term research agenda on temporary organizational forms (Editorial). Project-Based Organizing and Strategic Management, 28, xv-xxxix.

Cyert, R. M., \& March, J. G. (1963). A behavioral theory of the firm. Englewood Cliffs, NJ: Prentice Hall.

Davies, A., \& Brady, T. (2000).

Organisational capabilities and learning in complex product systems: Towards repeatable solutions. Research Policy, 29(7-8), 931-953. doi.org/10.1016 /S0048-7333(00)00113-X

Davies, A., \& Brady, T. (2016). Explicating the dynamics of project capabilities. International Journal of Project Management, 34(2), 314-327. doi.org/10.1016/j.ijproman.2015.04.006

DiMaggio, P. J., \& Powell, W. W. (1983). The iron cage revisited: Institutional isomorphism and collective rationality in organizational fields. American Sociological Review, 48(2), 147-160.

Dörrenbächer, C., \& Geppert, M. (2017). Multinational corporations and organization theory: Post millennium perspectives. Bingley, UK: Emerald Group Publishing Ltd.

Dvir, D., Lipovetsky, S., Shenhar, A. J., \& Tishler, A. (1998). In search of project classification: A non-universal approach to project success factors. Research Policy, 27(9), 915-935. doi.org/10 .1016/S0048-7333(98)00085-7

Edmondson, A. C., \& McManus, S. E. (2007). Methodological fit in management field research. Academy of Management Review, 32(4), 1155-1179. doi.org/10.5465/AMR.2007.26586086

Eisenhardt, K. M. (1989). Building theories from case study research. Academy of Management Review, 14(4), 532-550. doi. org/10.5465/AMR.1989.4308385

Eisenhardt, K. M., \& Graebner, M. E. (2007). Theory building from cases: Opportunities and challenges. Academy of Management Journal, 50(1), 25-32.

Ekstedt, E., Lundin, R. A., \& Wirdenius, H. (1992). Conceptions and renewal in Swedish construction companies. European Management Journal, 10(2), 202-209. doi.org/10.1016/0263-2373(92)90070-K 
Engwall, M. (2003). No project is an island: Linking projects to history and context. Research Policy, 32(5), 789-808. doi.org/10.1016/S0048-7333(02)00088-4

Engwall, M., \& Jerbrant, A. (2003). The resource allocation syndrome: The prime challenge of multi-project management? International Journal of Project Management, 21(6), 403-409. doi.org/10.1016/S0263-7863(02)00113-8 Engwall, M., \& Westling, G. (2004). Peripety in an R\&D drama: Capturing a turnaround in project dynamics. Organization Studies, 25(9), 1557-1578. doi.org/10.1177/0170840604048000

Eriksson, T., \& Kadefors, A. (2017). Organisational design and development in a large rail tunnel project-Influence of heuristics and mantras. International Journal of Project Management, 35(3), 492-503. doi.org/10.1016/j.ijproman 2016.12.006

Fetterman, D. M. (2010). Ethnography: Step-by-step (3rd ed.). Thousand Oaks, CA: Sage.

Galbraith, J. R. (1977). Organization design. Reading, MA: Addison-Wesley. Galbraith, J. R. (2014). Designing organizations: Strategy, process and structure at the business unit and enterprise level (3rd ed.). San Francisco, CA: Jossey-Bass.

Gann, D. M., \& Salter, A. J. (2000). Innovation in project-based, serviceenhanced firms: The construction of complex products and systems. Research Policy, 29(7-8), 955-972. doi.org/10 .1016/S0048-7333(00)00114-1

Ghoshal, S., \& Bartlett, C. A. (1990). The multinational corporation as an interorganizational network. Academy of Management Review, 15(4), 603-626. doi.org/10.5465/AMR.1990.4310825

Gibbert, M., Ruigrok, W., \& Wicki, B. (2008). What passes as a rigorous case study? Strategic Management Journal, 29(13), 1465-1474. doi.org/10.1002/smj.722 Glaser, B. G., \& Strauss, A. L. (1967). The discovery of grounded theory: Strategies for qualitative research. London, England: Wiedenfeld and Nicholson.
Grabher, G. (2004). Temporary architectures of learning: Knowledge governance in project ecologies. Organization Studies, 25(9), 1491-1514. doi.org/10.1177/0170840604047996

Hanisch, B., \& Wald, A. (2011). A project management research framework integrating multiple theoretical perspectives and influencing factors. Project Management Journal, 42(3), 4-22. doi.org/10.1002/pmj.20241

Hanisch, B., \& Wald, A. (2012). A bibliometric view on the use of contingency theory in project management research. Project Management Journal, 43(3), 4-23. doi.org/10.1002/pmj.21267

Henisz, W. J., Levitt, R. E., \& Scott, W. R. (2012). Toward a unified theory of project governance: Economic, sociological and psychological supports for relational contracting. Engineering Project Organization Journal, 2(1-2), 37-55. doi.org/10.1080/21573727.2011 .637552

Hobday, M. (2000). The project-based organisation: An ideal form for managing complex products and systems? Research Policy, 29(7-8), 871-893. doi.org/10.1016/ S0048-7333(00)00110-4

Hodgson, D. (2002). Disciplining the professional: The case of project management. Journal of Management Studies, 39(6), 803-821. doi.org/10.1111/ 1467-6486.00312

Kadefors, A. (1995). Institutions in building projects: Implications for flexibility and change. Scandinavian Journal of Management, 11(4), 395-408. doi.org/10.1016/0956-5221(95)00017-P

Keegan, A., \& Turner, J. R. (2002). The management of innovation in projectbased firms. Long Range Planning, 35(4), 367-388. doi.org/10.1016/ S0024-6301(02)00069-9

Kock, A., Heising, W., \& Gemünden, H. G. (2016). A contingency approach on the impact of front-end success on project portfolio success. Project Management Journal, 47(2), 115-129. doi.org/10.1002/pmj.21575
Kostova, T., Roth, K., \& Dacin, M. T. (2008). Institutional theory in the study of multinational corporations: A critique and new directions. Academy of Management Review, 33(4), 994-1006. doi.org/10.5465/ amr.2008.34422026

Lampel, J. (2011). Institutional dynamics of project-based creative organizations: Irving Thalberg and the Hollywood studio system. In Project-Based Organizing and Strategic Management (Vol. 28, pp. 445-466). doi.org/10.1108/S0742-3322 (2011)0000028020

Leavitt, H. J. (1965). Applied organizational change in industry: Structural, technological, and humanistic approaches. In J. G. March (Ed.), Handbook of Organizations (pp. 1144-1170). Chicago, IL: Rand McNally.

Lechler, T. G., \& Dvir, D. (2010). An alternative taxonomy of project management structures: Linking project management structures and project success. IEEE Transactions on Engineering Management, 57(2), 198-210. doi.org/10 .1109/TEM.2010.2044441

Levitt, R. E. (2012). The virtual design team: Designing project organizations as engineers design bridges. Journal of Organization Design, 1(2), 14-41. doi.org/10.7146/jod.1.2.6345

Lindkvist, L. (2004). Governing projectbased firms: Promoting market-like processes within hierarchies. Journal of Management and Governance, 8(1), 3-25. doi.org/10.1023/

B:MAGO.0000015392.75507.ad

Loufrani-Fedida, S., \& Saglietto, L. (2016). Mechanisms for managing competencies in project-based organizations: An integrative multilevel analysis. Long Range Planning, 49(1), 72-89. doi.org/10.1016/j.lrp.2014.09.001

Lundin, R. A., Arvidsson, N., Brady, T., Ekstedt, E., Midler, C., \& Sydow, J. (2015). Managing and working in project society: Institutional challenges of temporary organizations. Cambridge, UK: Cambridge University Press. doi.org/10.1007/9781139939454 
Lundin, R. A., \& Söderholm, A. (1995). A theory of the temporary organization. Scandinavian Journal of Management, 11(4), 437-455. doi.org/10.1016/ 0956-5221(95)00036-U

Manning, S. (2008). Embedding projects in multiple contexts-A structuration perspective. International Journal of Project Management, 26(1), 30-37. doi.org/10.1016/j.ijproman.2007.08.012

Martinsuo, M., Hensman, N., Artto, K., Kujala, J., \& Jaafari, A. (2006). Projectbased management as an organizational innovation: Drivers, changes, and benefits of adopting project-based management. Project Management Journal, 36(3), 87-97.

Meyer, J. W., \& Rowan, B. (1977). Institutionalised organisations: Formal structure as myth and ceremony. The American Journal of Sociology, 83(2), 340-363.

Middleton, C. J. (1967). How to set up a project organization. Harvard Business Review, (March/April), 73-82.

Miller, J. (1995). Lockheed Martin's skunk works. Leicester, UK: Midland Publishing Ltd.

Miterev, M. (2017). Organizing projectbased operations: The interplay of content, context and social processes. Stockholm, Sweden: KTH Royal Institute of Technology.

Miterev, M., Engwall, M., \& Jerbrant, A. (2016). Exploring program management competences for various program types. International Journal of Project Management, 34(3), 545-557. doi.org/10.1016/j.ijproman.2015.07.006

Miterev, M., Mancini, M., \& Turner, R. (2017). Towards a design for the projectbased organization. International Journal of Project Management, 35(3), 479-491. doi.org/10.1016/j.ijproman.2016.12.007

Miterev, M., Turner, J. R., \& Mancini, M. (2017). The organization design perspective on the project-based organization: A structured review. International Journal of Managing Projects in Business, 10(3), 527-549. doi.org/10.1108/IJMPB-06-2016-0048
Morris, P. W. G., \& Geraldi, J. G. (2011). Managing the institutional context for projects. Project Management Journal, 42(6), 20-32. doi.org/10.1002/pmj.20271

Müller, R. (2009). Project governance. Farnham, UK: Gower Publishing Ltd. doi.org/10.1093/ oxfordhb/9780199563142.003.0013

Nightingale, P., Baden-Fuller, C., \& Hopkins, M. M. (2011). Projects, project capabilities and project organisations. In G. Cattani, S. Ferriani, L. Frederiksen, \& F. Täube (Eds.), Project-based organizing and strategic management (Vol. 28, pp. 215-234). doi.org/10.1108/ S0742-3322(2011)0000028012

Packendorff, J. (1995). Inquiring into the temporary organization: New directions for project management research. Scandinavian Journal of Management, 11(4), 319-333. doi.org/10.1016/0956-5221(95)00018-Q Pascale, R. T., \& Athos, A. G. (1981). The art of Japanese management. New York, NY: Simon \& Schuster.

Pemsel, S., Müller, R., \& Söderlund, J. (2016). Knowledge governance strategies in project-based organizations. Long Range Planning, 49(6), 648-660. doi.org/10.1016/j.lrp.2016.01.001

Peters, T. J., \& Waterman, R. H. (1982). In search of excellence: Lessons from America's best-run companies. New York, NY: Harper and Row.

Prencipe, A., \& Tell, F. (2001). Interproject learning: Processes and outcomes of knowledge codification in projectbased firms. Research Policy, 30(9), 1373-1394. doi.org/10.1016/ S0048-7333(01)00157-3

Rich, B., \& Janos, L. (1994). Skunk works: A personal memoir of my years at Lockheed. Boston, MA: Little, Brown \& Co.

Schoonhoven, C. B. (1981). Problems with contingency theory: Testing assumptions hidden within the language of contingency "theory." Administrative Science Quarterly, 26(3), 349-377. doi.org/10.2307/2392512
Scott, W. R. (1995). Institutions and organizations. London, England: SAGE Publications, Inc.

Shenhar, A. J. (2001). One size does not fit all projects: Exploring classical contingency domains. Management Science, 47(3), 394-414. doi.org/10.1287/ mnsc.47.3.394.9772

Shenhar, A. J., \& Dvir, D. (1996). Toward a typological theory of project management. Research Policy, 25(4), 607-632. doi.org/10 .1016/0048-7333(95)00877-2

Söderlund, J. (2005). Developing project competence: Empirical regularities in competitive project operations. International Journal of Innovation Management, 9(4), 451-480. doi.org/10 $.1142 / S 1363919605001344$

Söderlund, J. (2008). Competence dynamics and learning processes in project-based firms: Shifting, adapting and leveraging. International Journal of Innovation Management, 12(1), 41-67. doi.org/10.1142/S1363919608001911

Suchman, M. C. (1995). Managing legitimacy: Strategic and institutional approaches. Academy of Management Review, 20(3), 571-610.

Suddaby, R. (2006). What grounded theory is not. Academy of Management Journal, 49(4), 633-642. doi.org/10.5465/ AMJ.2006.22083020

Sydow, J., Lindkvist, L., \& DeFillippi, R. (2004). Project-based organizations, embeddedness and repositories of knowledge: Editorial. Organization Studies, 25(9), 1475-1489. doi.org/10 $.1177 / 0170840604048162$

Sydow, J., \& Staber, U. (2002). The institutional embeddedness of project networks: The case of content production in German television. Regional Studies, 36(3), 215-227. doi.org/10.1080/00343400220122034

Teller, J., Kock, A., \& Gemünden, H. G. (2014). Risk management in project portfolios is more than managing project risks: A contingency perspective on risk management. Project Management Journal, 45(4), 67-80. doi.org/10.1002/ pmj.21431 


\section{Mechanisms of Isomorphism in Project-Based Organizations}

Van de Ven, A. H., Ganco, M., \& Hinings, C. R. (2013). Returning to the frontier of contingency theory of organizational and institutional designs. The Academy of Management Annals, 7(1), 393-440. doi.org/10.1080/19416520.2013.774981

Weber, M. (1978). Economy and society: An outline of interpretative sociology. Berkeley, CA: University of California Press.

Whitley, R. (2006). Project-based firms: New organizational form or variations on a theme? Industrial and Corporate Change, 15(1), 77-99. doi.org/10.1093/icc/dtj003

Whittington, R., Pettigrew, A., Peck, S., Fenton, E., \& Conyon, M. (1999). Change and complementarities in the new competitive landscape: A European panel study, 1992-1996. Organization Science, 10(5), 583-600.

Windeler, A., \& Sydow, J. (2001). Project networks and changing industry practices - Collaborative content production in the German television industry. Organization Studies, 22(6), 1035-1060. doi.org/10.1177/ 0170840601226006

Yin, R. K. (2009). Case study research: Design and methods (4th ed.). Thousand Oaks, CA: Sage.

Zika-Viktorsson, A., Sundström, P., \& Engwall, M. (2006). Project overload: An exploratory study of work and management in multi-project settings. International Journal of Project Management, 24(5), 385-394. doi.org/10 $.1016 /$ j.ijproman.2006.02.010

Maxim Miterev is a Postdoc in Project and Technology Management at KTH Royal Institute of Technology, Stockholm, Sweden. His research interests include program management, organizational design of PBOs, and innovation management. He has published in the International Journal of Project Management, Project Management Journa ${ }^{\circledR}$, and the International Journal of Managing Projects in Business. His research was recognized with several awards, including the IPMA Young Researcher Award 2016 and the IPMAPMI Best Paper Prize, EURAM 2017. He holds a double $\mathrm{PhD}$ degree in Industrial Economics and Management from KTH and Politecnico di Milano (Italy); a triple MSc in Strategic Project Management from Heriot-Watt University (UK), MIP-Politecnico di Milano (Italy) and Umeå University (Sweden); and an MSc in Applied Mathematics and Physics from Moscow Institute of Physics and Technology (State University). Before joining academia, Maxim worked as a management consultant with Roland Berger Strategy Consultants and an independent consultant; he also held analytical and managerial positions across the private and public sectors, including manufacturing, pharmaceutical, financial services, and regional development. He can be contacted at maxim.miterev@indek.kth.se

Mats Engwall holds the Chair in Industrial Management at KTH Royal Institute of Technology,
Stockholm, Sweden. His research revolves around the various features of neo-industrial management, including the projectification of organizations, management of industrial $R \& D$ processes, servitization of manufacturing firms, and the role of business model innovation in technology shifts. His publications have appeared in Harvard Business Review, Research Policy, Technovation, Organisation Studies, R\&D Management, International Journal of Production Economics, Research-Technology Management, International Journal of Project Management, and International Journal of Managing Projects in Business. He can be contacted at mats.engwall@indek.kth.se

Anna Jerbrant is an Associate Professor in the Department of Industrial Economics and Management, at KTH Royal Institute of Technology, Stockholm, Sweden. Anna holds both a PhD and an MSc in engineering degree from KTH, and since March 2017, has been the Dean of Education at the School of Industrial Engineering and Management at KTH. Anna's research is focused on increasing the understanding of the organizational challenges that contemporary project-based organizations and knowledge intensive business services (KIBS) face in a globalized world with continuously additional competition. Her research has been published in the Research-Technology Management, South African Journal of Economic and Management Science and the International Journal of Project Management, among others. She can be contacted at anna.jerbrant@indek.kth.se 
This material has been reproduced with the permission of the copyright owner. Unauthorized reproduction of this material is strictly prohibited. For permission to reproduce this material, please contact PMI. 